\title{
THE STATE OF ZOOPLANKTON COMMUNITIES IN THE LOWER DNIESTER AREA UNDER THE CONDITIONS OF RIVER REGULATION AND ACTUAL CLIMATIC CHANGES
}

\section{Liubovi Lebedenco', Mykhailo Nabokyn², Nadejda Andreev', Svetlana Kovalyshyna ${ }^{2}$}

\author{
${ }^{1}$ Institute of Zoology, Chisinau, Republic of Moldova \\ ${ }^{2}$ Ukrainian Scientific Center of Ecology of Sea, 89 Frantsuzsky Blvd., 65009, Odessa, Ukraine, \\ e-mail: liubovilebedenco@zoology.md,m.nabokin1@gmail.com
}

\begin{abstract}
The study focuses on zooplankton communities of the Lower Dniester. The quantitative indicators of plankton are given and the annual dynamics is described. An assessment of the current state of the river according to the state of zooplankton communities is presented, together with a comparison with historical data, at different stages of river regulation. The changes that occurred in the river zooplankton since the 1950s were analyzed. The relationships between individual characteristics of planktonic communities and the physical and chemical characteristics of the river was also investigated. A comparison of actual data with those collected during 70-80s revealed no significant changes in the structure of the zooplankton community. The proportion of different groups of zooplankton organisms changed insignificantly, the saprobity indices improved slightly, and the average zooplankton biomass did not change. However, compared to the period before 1950s, prior to river regulation for hydropower purposes the role of rotifers in the community was reduced. It might be difficult to identify the main factor determining the development of zooplankton in the Lower Dniester, in order to understand the processes taking place in planktonic communities, it is necessary to analyze the complex impact of hydrological and hydrochemical factors on planktonic communities.
\end{abstract}

\section{Introduction}

The Dniester is one of the four largest rivers in Ukraine, the largest river in Moldova, and the biggest source of freshwater in Ukraine and the only major source in Moldova.

In recent years, several factors, including the hydrochemical and hydrobiological status of the river ecosystems have produced significant changes.

Dniester river has undergone significant modifications, following the construction of the Dubasari (1953) and Novodnestrovsc (1980) reservoirs, which caused the rupture of the longitudinal connectivity of the river, the disruption of the hydrological, thermal and hydrochemical regimes. This resulted in harmful effects first of all on the hydromorphological balance of the rivers, but also on the aquatic fauna and habitats. Therefore, the ecological state of the river is of particular interest for research and monitoring.

Since anthropogenic pollution is multifactorial, in order to assess the effect of its impact on aquatic ecosystems, it is necessary that along with physicochemical studies, observations of the state of communities of aquatic organisms are carried out. In appraising the state of aquatic ecosystems according to hydrobiological parameters, zooplankton is one of the main biotic components and has an extremely important role in the structure and functioning of ecosystems, including participation in self-purification processes.

Zooplankton is a multi-species community, in which, as a rule, the following groups of 
invertebrates are distinguished: rotifers (Rotatoria), cladocerans (Cladocera) and copepods (Copepoda). Changes in the structure of zooplankton are of great importance in the functional organization and state of the entire aquatic ecosystem [11].

The hydroecological history of Dniester River and Dniester estuary may be divided into three periods: 1. pre-regulated period; 2. partly regulated period (starts in 1954 after Dubossary Reservoir and the Dubossary Hydroelectric Power Plant were put into operation); 3. fully regulated period (from 1983 when the Dniester Reservoir and the Dniester Hydroelectric Power Plant were put into operation).

Although the research papers on the state of zooplankton in the lower Dniester were published in the first half of the last century, most of them were either purely faunistic, without describing the quantitative characteristics, focusing on peculiarities of the ranges of certain species $[6,14]$, or describing only small sections of the river basin. Complex studies on the topic were undertaken only in the 50s of the last century - Markovsky, Yaroshenko and Grimalsky $[10,15,23]$.

These studies provided detailed information on the taxonomic composition, spatial and seasonal variability of the zooplankton. Some brief data on the zooplankton of the Lower Dniester and Dniester delta were given in the works of Burnashev [7, 8], Grimalsky in 1968 [9]. Large-scale studies on zooplankton in the lower Dniester was done in the work carried out by Naberezhny, Climenco, [4, 12, 13, 16, 17].

However, the first author offered rather a brief description of the zooplankton, without referring particularly to the Lower Dniester, and the second author considered data only from the seasonal point of view.

Thus, the latest studies of zooplanktonic communities in the lower Dniester were carried out mainly in the spring-summer period, as the periods of the greatest development of zooplanktonic organisms. However, the year-around monitoring can reflect the effect of climatic changes on plankton even more clearly than only monitoring in the spring and summer, for example, changes in the quantitative and qualitative structure of communities as a result of changes in the timing of plankton development.

Therefore, now it becomes critically important to study the annual dynamics of zooplankton communities and revealing the patterns of the changes occurring at biocenosis level.

The paper was elaborated on the basis of data obtained under BSB27 " Black Sea Basin interdisciplinary cooperation network for sustainable joint monitoring of environmental toxicants migration, improved evaluation of ecological state and human health impact of harmful substances, and public exposure prevention (MONITOX)”, BSB165 „Creating a system of innovative transboundary monitoring of the transformations of the Black Sea river ecosistems under the impact of hydropower development and climate change", State Program 20.80009.7007.06 Determining the changes of aquatic environment, assessing the migration and impact of pollutants, establishing the patterns of the functioning of hydrobiocenoses and preventing the negative effects on ecosystems, and the part of ecological monitoring of Lower Dniester National Nature Reserve. 


\section{Materials and methods}

This paper presents the results of investigations of zooplankton communities of the Dniester river, in the lower sector (Vadul lui Voda - Palanca) on the territory of the Republic of Moldova and the delta Dniester river (Palanca - Maiaki) of Ukraine. Zooplankton samples on Lower Dniester were collected during 2020, linearly including all seasons as part of the complex research of the Laboratory of Hydrobiology and Ecotoxicology of the Institute of Zoology. The complex expeditions were carried out on the Lower Dniester ecosystem (Vadul lui Voda, Varnita, Sucleia, Palanca).The zooplankton sampling from Dniester delta was collected on all seasons, on two monitoring points near the village Mayaki and near the 51-th $\mathrm{km}$ of road Odessa-Reni (st.Palanca) by the Ukrainian Scientific Centre of Ecology of the Sea. The collection of zooplankton material was performed together with hydrological, hydrochemical and other biological samples. Sampling and subsequent processing was carried out by standard methods $[1,3]$. The samples were collected using the Apstein zooplankton net (№ 55) by filtering a quantity of 1001 of water. The collected zooplankton material was fixed immediately in the field with formalin solution (40\%). The quantitative counting of zooplankton was carried out using Bogorov counting chamber and the binocular stereo zoom Discovery V8 ZEISS, using three replications. The density $(\mathrm{N}-\mathrm{ind} / \mathrm{m} 3)$ of the organisms was calculated to cubic meter. Identification of the main zooplankton groups (Rotatoria, Copepoda, Cladocera) was carried out up to the highest possible level, with the use of the microscope Axio Imager A.2 (Zeiss). The determination of the taxonomic structure of the zooplankton groups was carried out with the use of identification guides $[16,21]$ The estimation of the investigated aquatic ecosystems and water quality was performed by saprobiological analysis based on an existing saprobiont system $[3,5]$.

\section{Results and Discussion}

Research on the monitoring of zooplankton communities in the borders of the Republic of Moldova in the Dniester ecosystem, including its medial and lower sector, began in the 1947s and is reflected in numerous works $[4,16,17,22]$.

During 2020, the development of zooplankton in the Lower Dniester showed both seasonal and within station variations. The specific diversity of zooplankton during 2020 in the lower sector of the Dniester (Vadul lui Voda - Palanca) was represented by 72 taxonomic units (fig. 1), with the predominance of the group of rotifers which constituted $64 \%$ or 46 taxonomic units of the total number. Copepods were represented by $15(21 \%)$ taxonomic units including the stages of nauplii and copepods and cladoceres 11 units or $15 \%$. The diversity of zooplankton in the Dniester delta constituted 37 taxonomic units: Rotatoria - 23 (62\%), Cladocera 5 (13\%), Copepoda -4 (11\%) and other groups of organisms (Varia) - 5 (14\%) taxonomic units fig 1, b. As reflected in previous investigation published earlier [18, 19], the main share in the formation of specific diversity in the investigation period belongs to rotifers. 
a

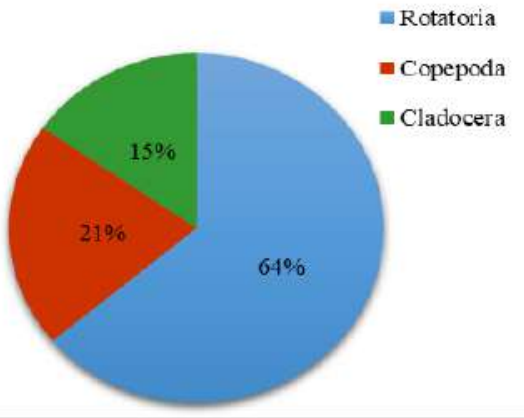

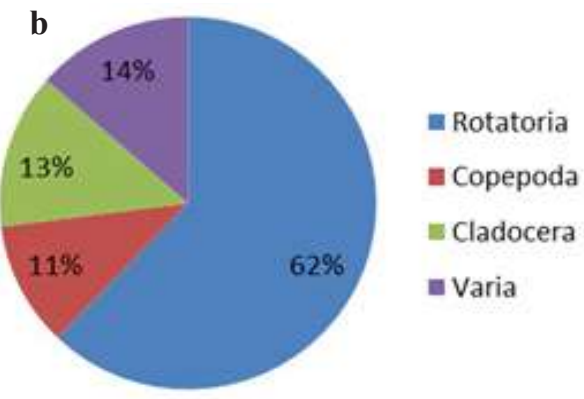

Figure 1. Taxonomic diversity and the contribution of the main groups of zooplankton in the Lower Dniester, 2020

It is known that the composition of zooplankton communities can differ significantly depending on the geographical conditions of the researched areas, but also on different hydrological, chemical and biotic factors. The specific diversity during the year along the river varied within the limits of 4-45 taxonomic units, with the specific richness increased at st. Palanca.

Following the abundant rainfall, during 2020, which conditioned the overflow of large waters and the flooding of some sectors of the ecosystem of Dniester river, in the composition of riparian zooplankton more and more limnophilous species appear, with increased preferences for organic substances such as Platyias quadricornis (Ehrenberg, 1838), Brachionus calyciflorus Pallas, 1776, Brachionus budapestinensis Daday, 1885, Echlanis dilatata Ehrenberg, 1832, Filinia longiseta (Ehrenberg, 1834) species that prefer vegetation thickets - e.g. Lophocharis oxysternon (Gosse, 1851), Lecane (Monostyla) closterocerca (Schmarda, 1859) and species characteristic for swampy areas - Eudactylota eudactylota (Gosse, 1886) (st. Palanca).

From the analysis of the data of the last three years, related to the qualitative composition of zooplankton organisms, a trend of increasing specific diversity along the Lower Dniester river was observed. Figure 2 shows the distribution of the number of taxa registered on the Lower Dniester in the dynamics, during 2020 and previous two years.

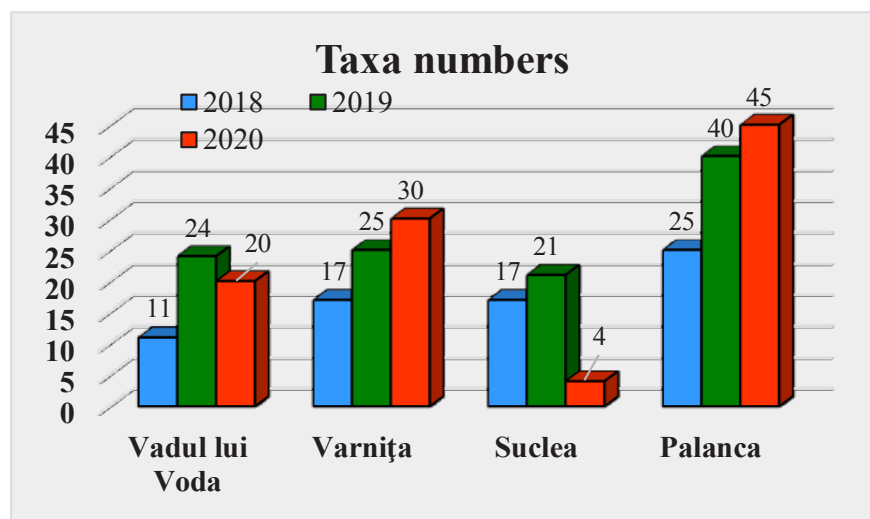

Figure 2. Distribution of the number of zooplankton taxa along the Lower Dniester during 2018-2020 
From the obtained data, an increase in the composition of zooplankton diversity from 2018 to 2020 at all sampling stations could be seen.

The increase in the diversity and quantitative parameters in the Lower Dniester sector during 2020 was not only due to favorable climatic conditions and factors linked to this period but also to the more often sample collection (monthly) during 2020. Along the Lower Dniester River up to the river mouth, zooplankton diversity increased to 45 taxonomic units (st.Palanca).

The peculiarities of the qualitative structure and quantitative composition of zooplankton were mainly determined by the hydrological regime of the Lower Dniester, which is unstable and directly dependent on the hydrological regime of the Dubasari reservoir, thus favoring the proliferation of zooplankton in the Lower Dniester. The data showed that, the contribution of the Dubasari accumulation lake to the formation of zooplankton community in the lower Dniester is insignificant. At Vadul lui Voda st. the lowest values of composition and development of zooplankton (fig. 2-3) was observed, with an increase towards the river mouth. The reduction of the composition of specific diversity and quantitative parameters of zooplankton development at Sucleia station was influenced by the hydrological conditions as well as by unfavorable sanitary-biological conditions due to discharge of industrial-municipal wastewater.

Quantitative development of zooplankton in the the Dniester river during 2020 [2] was largely determined by unstable climatic conditions and water level fluctuations, which led to an increase in the development of the number, compared to previous years, when the main contribution to the formation of zooplankton biomass was made up by rotifers, and to the formation of crustacean biomass, especially copepods. The average density (figure $3 \mathrm{~A}-\mathrm{B}$ ) of the zooplankton of lower Dniester during 2020 varied in the limits of $1.4-96.9$ thousand ind /m3, with a maximum development at Palanca station and minimum at Sucleia station.
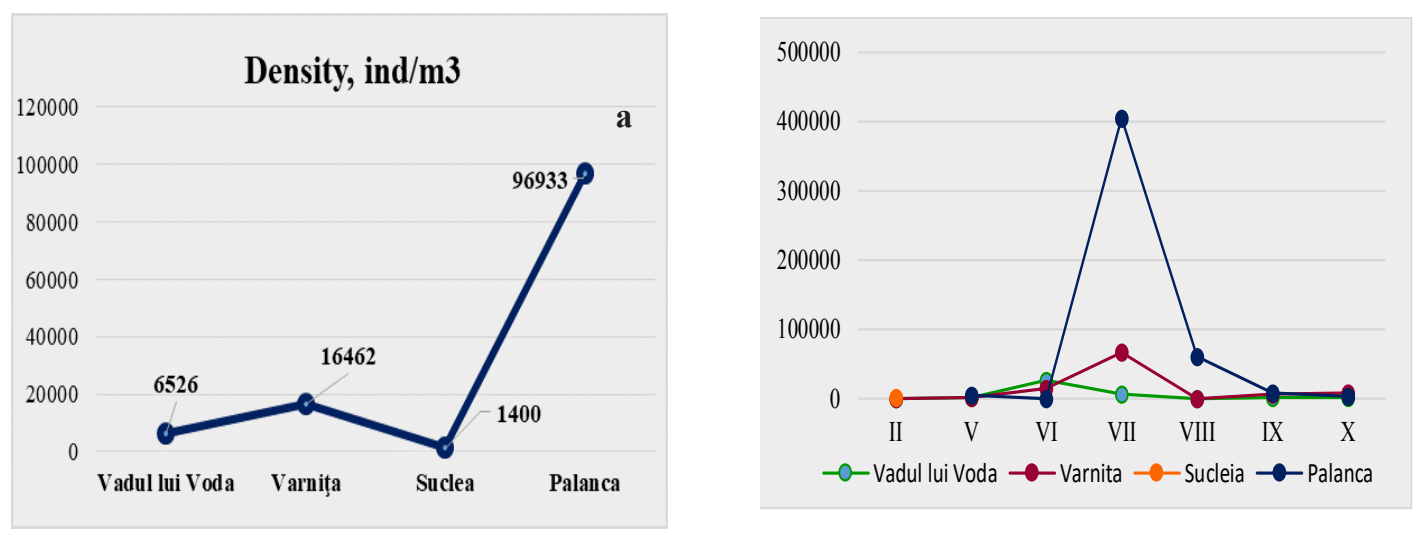

Figure 3. Abundance (A) of zooplankton and seasonal distribution the density (B) on the course of Lower Dniester during 2020

Along the river, from Vadul lui Voda station to Varnita, an increase in the abundance of zooplankton by 2.5 times was observed, however a decrease towards st. Sucleia and a significant increase in st. Palanca, where the average value of the density was 96.9 thousand ind / 
$\mathrm{m} 3$ was encountered. The less favorable conditions were encountered at Varnita station, where the average values of the abundance was 1400 ind / 3. Figure 3B shows the parameters of the number of zooplankton communities during the investigation period. In the seasonal aspect, at all monitoring points, both the specific diversity and the quantitative parameters of the lower Dniester zooplankton reached the maximum values in July-August.

Quantitative indicators of the seasonal development of different zooplankton groups from Dniester Delta are shown in Figure 4. It is noteworthy that although the first maximum of development was the largest by abundance, the largest by biomass was the second maximum, which occurred in September.
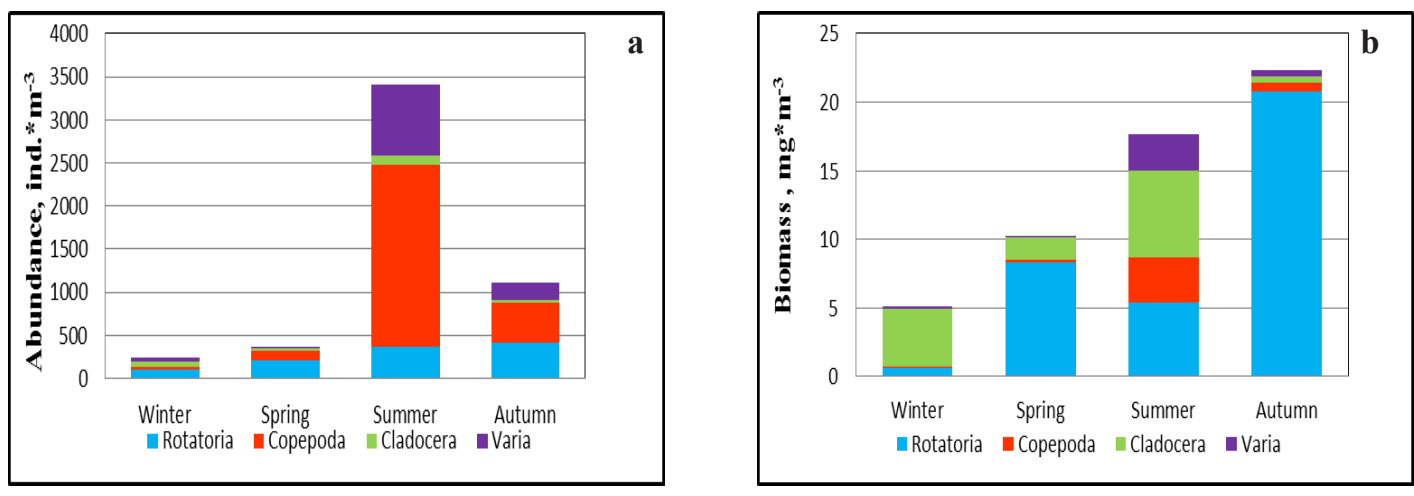

Figure 4. The abundance and biomass of different groups of zooplankton in the Dniester delta in $\mathbf{2 0 2 0}$

In regard to the seasonal changes of zooplankton community in the Dniester delta and inferior Dniester, the species diversity and quantitative characteristics in winter were low. Only rotifers of the genus Notholka Gosse, 1886, Brachionus Pallas, 1766 were abundant. In addition, the cladocerans Chydorus sphaericus (O.F. Müller, 1776) was numerous in the Dniester delta and in the Inferior Dniester river sector during the winter season. There were also rotifers of the genera, Asplanchna Gosse, 1850, Filinia Bory de St. Vincent, 1824, Lecane Nitzsch, 1827 as well as nauplii of copepods. In spring, there was an increase in the diversity and biomass. Copepods of the genera Acanthocyclops Kiefer, 1927, Eucyclops Claus, 1893 and Eudiaptomus Kiefer, 1932 appeared in the samples. The variety of rotifers in Dniester delta increased, the first maximum of development occurred in June. Also, in June there was a maximum of Cladocera variety, which together with rotifers formed most of mesozooplankton biomass. The second maximum occurred in September and was formed mainly by rotifers and copepods. In October, abundance began to decline and in November became typical for winter. The group of cladocerans in the lower Dniester sector were underdeveloped and were not constantly present during the investigation period, which usually, make a significant contribution to the formation of zooplankton biomass.

In Dniester delta rotifers formed the basis of species diversity throughout the entire observation period. In the spring, they also were the dominant group by abundance. During 2019-2020 
$[19,20]$ rotifers dominated by abundance in most months and made a significant contribution to biomass. In other years, in different months, the main contribution to the abundance and biomass was made by copepods and cladocerans. Other organisms during the entire observation period did not contribute significantly to the species diversity and for most of the observation period did not make a significant contribution to the abundance and biomass. When comparing the obtained data with historical data, one can note the absence of significant changes in the current structure of the community since the $70 \mathrm{~s}$, when the river was already regulated. The proportion of different groups of organisms changed only insignificantly, the saprobity indices improved slightly, and the biomass practically did not change. However, when comparing actual data with the changes that occurred place before 1950s, a tendency of decreasing of the role of rotifers in the community was observed, that might be related to a decrease in the water level of the delta. This assumption was forwarded by Naberezhny [18], who mentioned a change in the ratio towards rotifers in years with high water level. Nevertheless, no clear relationship was found between the proportion of rotifers and runoff volumes. There are also no significant correlations between the indicators of zooplankton and phytoplankton biomass, as well as any measured hydrophysical and hydrochemical parameters (Fig. 5), with the exception of water temperature, for which a correlation with $r=0.55$ to $r=0.63$ was revealed with different indicators of zooplankton. It is noteworthy that a weak negative correlation was observed with most chemical parameters such as salinity, $\mathrm{pH}$, oxygen, phosphorus, nitrogen. It might be difficult to identify the main factor determining the development of zooplankton. To understand the processes occurring in the zooplankton community, it is necessary to analyze the complex impact of hydrological and hydrochemical factors.

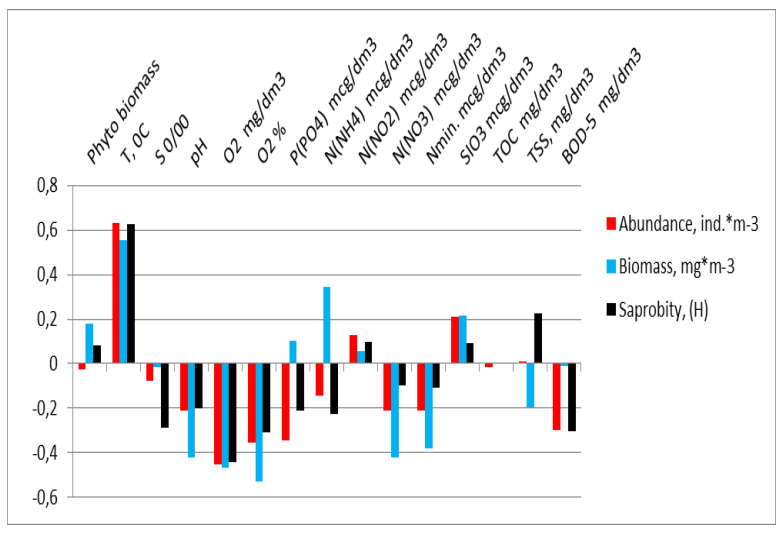

Figure 5. Correlations between zooplankton parameters and hydrochemical indicators

During 2020, significant fluctuations of the saprobic index in the Lower Dniester in the seasonal aspect and in different sectors of it were observed. In the lower sector of the Dniester river, species with a preference for the $\beta$-mesosaprobic zone predominated. The values of the saprobic index varied during the winter in the limits of 2.29-2.50 and in the spring in the limits of 1.30-1.65, in summer between 1.72-1.84 and in autumn between 1.28-1.79. During the Low- 
er Dniester, the value of the saprobic index is presented in figure 6 and varied in the limits of 1.60 - 2.29. The maximum value at Sucleia station, due to the presence of the genus Brachionus Pallas 1766, attests to the higher content of organic substances and pollution of the given area.

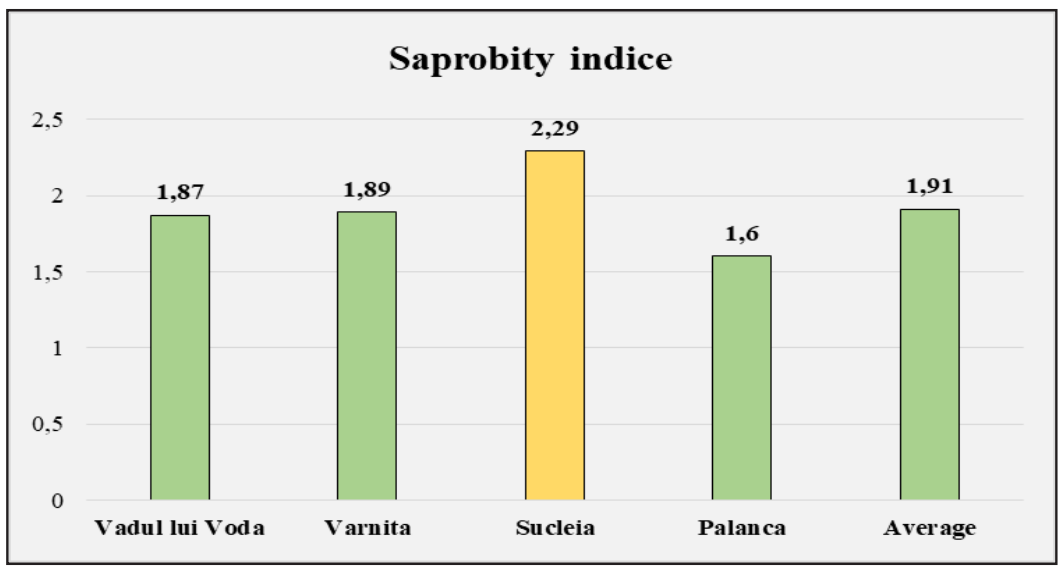

Figure 6. Variation of saprobic index and water quality class in the lower Dniester river sector, 2020.

The average value of saprobic index in the Lower Dniester was 1.91 (Fig. 6), that falls within the II class limit of water quality as "good". Saprobity index in the Dniester delta by zooplankton indicators varied from 1.56 in February to 2.44 in June (fig. 7), on average per year of 1.62, which corresponds to $\beta$-mesosaprobic zone (moderately polluted waters). It is noteworthy that the values of index were slightly better compared with 70th of XX century, when it was 1.88 [18].

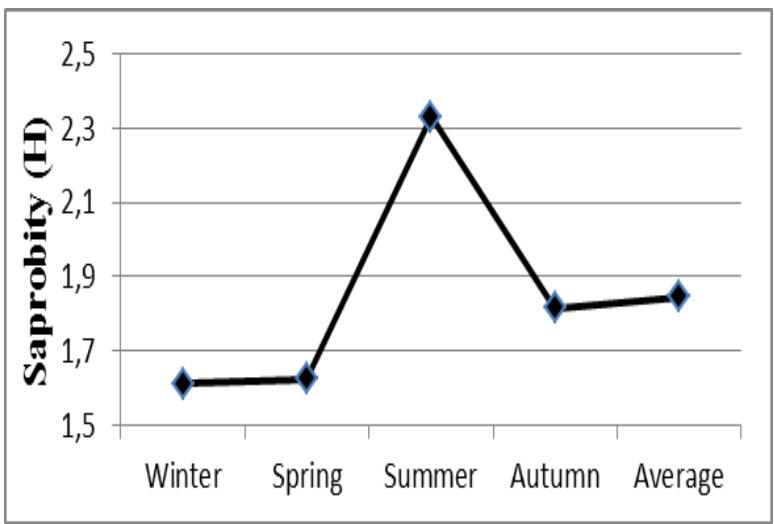

Figure 7. Seasonal variation of saprobity index for zooplankton in the Dniester delta in 2020

The ecological status of the investigated ecosystems, according to the parameters of the zooplankton communities corresponds to the b-mesosaprobe area, and the water quality according to the values of the saprobity index is attributed to classes II - III and is characterized as good - moderately polluted [5]. 


\section{Conclusions}

The state of the Dniester River was studied in detail in the middle of the last century; however, climate change and active hydropower construction and the changes caused by them require updating of the data. When comparing the modern with the historical ones, a moderate improvement in the state of the zooplankton community was noted during 2018-2020, in comparison with years $70 \mathrm{~s}$ and $80 \mathrm{~s}$, when the river was already regulated. The proportion of different groups of zooplankton organisms changed insignificantly, the saprobity indices improved slightly, and the average zooplankton biomass did not change. However, when considering the changes occurring since the 1950s, there was a clear tendency towards a decrease in the role of rotifers in the community. This may be due to a decrease in water level in the delta. A clear relationship between the share of rotifers and runoff volumes was not found, but an inverse relationship between the total abundance and runoff volumes was visible. In general, there is a tendency to improve the state of the river in comparison with the $70 \mathrm{~s}$, when the maximum eutrophication of the water area was observed. However, no significant correlations were found between hydrophysical and hydrochemical parameters and planktonic communities. To understand the processes occurring in planktonic communities, it is necessary to do a comprehensive analysis of the complex impact of hydrological and hydrochemical factors on planktonic communities.

Acknowledgements. The authors are thankful to the EU Black Sea Joint Operational Programme 2014-2020 for the funding of the project with eMS code eMS BSB165 "Creating a system of innovative transboundary monitoring of the transformations of the Black Sea river ecosystems under the impact of hydropower development and climate change" and BSB 27 “ Black Sea Basin interdisciplinary cooperation network for sustainable joint monitoring of environmental toxicants migration, improved evaluation of ecological state and human health impact of harmful substances, and public exposure prevention MONITOX". The content of this publication is sole responsibility of the authors and does not reflect the views of the European Union.

\section{Bibliography}

1. Jurminskaia O., Subernetkii I., Lebedenco L. Sampling of zooplankton. In: Toderaș I., Zubcov E., Biletski L. (editor) Hydrochemical and hydrobiological sampling guidance. Elan poligraf. Chişinău: 2015, p. 14-18.

2. Lebedenco L. Evaluarea stării comunităților zooplanctonice în condițiile schimbării mediului acvatic. În Modificări funcționale ale ecosistemelor acvatice în contextul impactului antropic și al schimbărilor climatice.- Chisinau: S.n., 2020. p. 42-45.

3. Lebedenco L., Jurminskaia O., Andreev N. Zooplankton. In Guidance on the Monitoring of Water Quality and Assessment of the Ecological Status of Aquatic Ecosystems/ editors: Biletchi Lucia, Zubcov Elena.-Chisinau: S. n., 2021. - 92p.

4. Naberejnâi, A., Esaulenco, V., Climenco, V. Diversitatea specifică şi producţia zooplanctonului în ecosistemele acvatice ale Moldovei. În Diversitatea şi ecologia lumii animale în ecosistemele naturale şi antropizate. Chişinău: Institutul de Zoologie, 1997, p. 130-131.

5. Regulament cu privire la cerinţele de calitate pentru apele de suprafaţă. HG RM nr. 890 din 12.11.2013. Chişinău: Monitorul Oficial nr. 262 - 267, 22 noiembrie 2013. 
6. Бенинг А. Л. Понто-каспийские элементы в р. Днестр. Русский гидробиологический журнал, 1929, т. VII. № 10-12.

7. Бурнашев М. С, Ракитина Н. П. Состояние кормовой базы рыб и возможная рыбопродуктивность низовьев Днестра после зарегулирования. Уч.зап. Тираспольского госпединститута, Кишинев. 1970, т.ХУІІ.

8. Бурнашев М. С. Рыбохозяйственная характеристика нижнего бъефа р. Днестр // Тр. Зональн. Совещ. по типологии и биол. обоснов. рыбохоз. использов. внутр. (пресноводных) водоёмов южной зоны СССР. 1962, с. 67-72.

9. Гримальский В. Л. Зоопланктон Дубоссарского водохранилища. Ученые записки Кишиневского Государственного Университета. 1968, с. 3-62.

10. Гримальский В.Л. Планктон реки Днестр. Тр. Кишиневск. с-х. ин-та. 1957, № 12, с. 3-86.

11. Карташева Н.В., Фомин Д.В., Попов А.В., Кучкина М.А., Минин Д.В. Оценка техногенного воздействия на зоопланктон водоёмов-охладителей атомных и тепловых электростанций. Вестник Московского университета. Серия 16: Биология, том 16, № 3 , М.: Изд-во Моск. ун-та. 2008. с. 30-35.

12. Клименко В. Многолетние сукцессии зоопланктона в нижнем Днестре. În Ecologia, evoluţia şi ocrotirea diversităţii regnului animal şi vegetal. Chişinău: 2003, p. 78-80.

13. Клименко В. Особенности развития зоопланктона реки Днестр в засушливые и маловодные годы. Интегрированное управление природными ресурсами трансграничного бассейна Днестра: Материалы Междун. конференции, Кишинэу, 2004, с. 159-161.

14. Макаров А. К. Распространение некоторых ракообразных и лиманных моллюсков в устьях рек и открытых лиманах Северного Причерноморья.Зоол. журн.- 938.- №. 6.

15. Марковский Ю. М. Фауна беспозвоночных низовьев рек Украины условия ее существования и пути использования. Издательство Академии Наук Украинской ССР, 1953.

16. Набережный А.И. Коловратки водоёмов Молдавии. Кишинёв: Штиинца, 1984.

17. Набережный, АИ., Есауленко, ВА. Зоопланктон и его значение в продукционнодеструкционных процессах. В: Экосистема нижнего Днестра в условиях усиленного антропогенного воздействия. Кишинев: Штиинца, 1990, с. 160-168.

18. Набережный А.И. Зоопланктон нижнего Днестра в условиях антропогенного воздействия. Сборник «Биогидроресурсы бассейна Днестра, их охрана и рациональное использование». Кишинёв, 1980, с. 87-103.

19. Набокин М. В. Ковалишина С. П. Анализ сезонных изменений в зоопланктоне дельты Днестра. Hydropower Impact on River Ecosystem Functioning. 2019, с. 257-260.

20. Набокин М. Многолетние изменения в зоопланктоне дельты Днестра //EU Integration and Management of the Dniester River Basin. 2020, 236-239 c.

21. Определитель зоопланктона и зообентоса пресных вод Европейской России. Том 1. Зоопланктон. Ред. Алексеев В. Москва - С.-Петербург, 2010. 495 с.

22. Сиренко Л. А. и др. Гидробиологический режим Днестра и его водоемов. Киев: Наукова думка, 1992, с. 197-211.

23. Ярошенко М.Ф. Гидрофауна Днестра. М.: Изд-во АН СССР. 1957, 169 с. 